\title{
Antioxidant Activity of Pitcher Extracts from Three Nepenthes Species
}

(Aktiviti Antioksidan Ekstrak Kendi bagi Tiga Spesies Nepenthes)

\author{
Muhammad Aqil Fitri Rosli, KamalRul AZlan AZIZAN \& HoE-Han GOH*
}

\begin{abstract}
Nepenthes, locally known as 'periuk kera' in Malaysia, is a fascinating species due to uniqueness in their morphology in having pitcher organ for carnivorous diet. The pitcher plant has been used for cooking traditional delicacies and as traditional remedies to treat illness. Hence, this species might possess beneficial health properties. This study aimed to compare the antioxidant activity of the pitcher extracts from Nepenthes ampullaria, Nepenthes rafflesiana and their hybrid, Nepenthes $\times$ hookeriana. The samples were extracted using methanol:chloroform:water (3:1:1) via sonication assisted extraction and the extracts were subjected to three different antioxidant assays, namely 2,2-diphenyl-1-picrylhydrazyl (DPPH), ferric reducing power (FRAP) and total phenolic content (TPC). Extract from $\mathrm{N}$. ampullaria exhibited the strongest radical scavenging activity $(0.148 \pm 0.04 \mathrm{mg} / \mathrm{mL})$ with the highest ferric reducing power $(0.009 \pm 0.003 \mathrm{mg} \mathrm{GA} / \mathrm{mg}$ dry weight) among the three species, whereas that of $\mathrm{N}$. rafflesiana possessed the highest phenolic content (0.057 $\pm 0.017 \mathrm{mg} \mathrm{GA} / \mathrm{mg}$ dry weight). However, the antioxidant capacities of the pitcher extracts were not significantly different $(\mathrm{p}>0.05)$ between the three species and were much lower than the gallic acid as a standard reference.
\end{abstract}

Keywords: Antioxidants activity; DPPH assay; ferric reducing power assay; Nepenthes sp.; total phenolic content

\section{ABSTRAK}

Nepenthes, lebih dikenali sebagai 'periuk kera' di Malaysia merupakan suatu spesies yang menakjubkan kerana keunikan morfologinya dalam mempunyai organ seperti kendi untuk diet karnivor. Tumbuhan berkendi ini telah digunakan dalam masakan tradisi dan juga sebagai ubat-ubatan tradisi untuk merawat penyakit. Oleh itu, spesies ini mungkin memiliki kandungan yang bermanfaat untuk kesihatan. Kajian ini bertujuan untuk membandingkan aktiviti antioksidan ekstrak kendi daripada Nepenthes ampullaria, Nepenthes rafflesiana dan hibrid mereka, Nepenthes $\times$ hookeriana. Setiap sampel telah diekstrak dengan menggunakan metanol:kloroform:air (3:1:1) melalui pengekstrakan dengan bantuan sonikasi dan telah diasai dengan tiga asai antioksidan yang berbeza, iaitu 2,2-diphenyl-1-picrylhydrazyl (DPPH), kuasa penurunan ferik (FRAP) dan jumlah kandungan fenolik (TPC). Ekstrak daripada N. ampullaria menunjukkan aktiviti pelupusan radikal yang terkuat $(0.148 \pm 0.04 \mathrm{mg} / \mathrm{mL})$ dan mempunyai kuasa penurunan ferik yang tertinggi $(0.009 \pm 0.003 \mathrm{mg}$ $\mathrm{GA} / \mathrm{mg}$ berat kering) antara ketiga-tiga spesies ini, namun begitu N. rafflesiana mempunyai kandungan fenolik yang tertinggi (0.057 $\pm 0.017 \mathrm{mg} \mathrm{GA} / \mathrm{mg}$ berat kering). Walau bagaimanapun, tiada perbezaan signifikan terhadap kebolehan antioksidan ekstrak kendi daripada tiga spesies yang dikaji dan ternyata jauh lebih rendah daripada asid galik yang merupakan piawai rujukan dalam kajian ini.

Kata kunci: Aktiviti antioksidan; asai DPPH; asai jumlah kandungan fenolik; asai kuasa penurunan ferik; Nepenthes sp.

\section{INTRODUCTION}

Reactive oxygen species (ROS) could be defined as free radicals containing oxygen produced in living tissue (Diplock et al. 1998). These free radicals are highly reactive chemicals which have the potential to harm cells. ROS are constantly produced in the cells as the signalling components in stress responses, radiation, bacterial and viral toxin, smoking, alcohol and psychological or emotional stress in humans (Onoja et al. 2014). On the contrary, high levels of ROS are harmful and can lead to ageing and cell damage or development of cancer and some other diseases such as Alzheimer's disease, diabetes, atherosclerosis, neurodegenerative disease and cancer (Khalaf et al. 2008; Patel et al. 2010).
Therefore, antioxidants are used as health supplements to protect and prevent such damages from ROS. Antioxidant molecules or known as the free radical scavengers are chemicals that could interact with free radicals, chelating metals and performed as oxygen scavengers (Onoja et al. 2014). These antioxidants are available naturally in plants or as synthetic compounds. Several synthetic antioxidants such as butylated hydroxyanisole (BHA), butylated hydroxytouluene (BHT), tertiary butylated hydroxyl quinone (TBHQ) and gallic acid esters are also available commercially. These synthetic antioxidants are widely used in food industry to prevent food oxidation and increase shelf life, but there are certain concerns on their safety and toxicity (Carocho \& Ferreira 2013; Patel et al. 
2010; Reddy \& Grace 2016). Hence, there has been an increasing interest and demand for natural antioxidants, especially from industries related to cosmetics, foods and pharmaceuticals on bioactive compounds from natural products and medicinal plants to substitute synthetic antioxidants (Barros et al. 2007; Thao et al. 2016).

Nepenthes species is a tropical carnivorous pitcher plant from the family of Nepenthaceae. The plant is native and highly distributed in Southeast Asia of Peninsular Malaysia, Singapore, Sumatera and Borneo (Adam \& Hamid 2007; Moran et al. 2010). The Nepenthes plant is fascinating to study because of their carnivorous diet with unique pitcher organ growing from the tip of leaf (Wang et al. 2009). Furthermore, hybridisation that is extensive in Nepenthes could also lead to variations and unique phytochemical production (Lätti et al. 2011). Traditionally, the Nepenthes plant is commonly used as folk medicine to regulate the menstrual cycle, ease child birth, relieve asthma, treat eye inflammation, gastric ulcer, jaundice, high blood pressure and also as an astringent (Aung et al. 2002; Sanusi et al. 2017; Thao et al. 2016; Van Thanh et al.2015). Collectively, the pitcher has also been used to cook traditional delicacies (Schwallier et al. 2015).

Previously, the leaf extract of the Nepenthes plant has been reported to contain many beneficial bioactivity properties, including antibacterial, antifungal, antimalarial, antiosteoporotic, and antidiabetic (Likhitwitayawuid et al. 1998; Shil et al. 2010; Shin et al. 2007; Van Thanh et al. 2015). In contrast, the chemical analysis of the pitcher tissue is still lacking with no previous report on its antioxidant activity. It is interesting to study the pitcher since the tissue is elongated from the leaf and only unique to Nepenthes species. In this study, the pitcher extracts from three related lowland Nepenthes species, namely Nepenthes ampullaria, Nepenthes rafflesiana and their hybrid, Nepenthes $\times$ hookeriana were compared on their antioxidant activity via 2,2-diphenyl-1-picrylhydrazyl (DPPH) assay, ferric reducing power (FRAP) assay and total phenolic content (TPC).

\section{MATERIALS AND METHODS}

\section{PITCHER SAMPLING AND PHYTOCHEMICAL EXTRACTION}

Mature pitchers of three lowland Nepenthes species, $N$. ampullaria, $N$. rafflesiana and $N . \times$ hookeriana were sampled in the morning between 9 and 11 am, about 7 days after the pitcher opening from a terrace at Universiti Kebangsaan Malaysia (2॰55'12.7'N, 10146’59.7'E). Each pitcher represents a biological replicate, with 5 biological replicates and 5 technical replicates in this study. The collected samples were lyophilised and $10 \mathrm{mg}$ of dried samples were extracted with $200 \mu \mathrm{L}$ of methanol: chloroform: water $(3: 1: 1)$ via sonication for $15 \mathrm{~min}$ according to Rosli et al. (2017). Filtered extracts through a $0.22 \mu \mathrm{m}$ PTFE membrane were stored at $-80^{\circ} \mathrm{C}$.

\section{2,2-DIPHENYL-1-PICRYLHYDRAZYL (DPPH) ASSAY}

DPPH radical-scavenging-activity was determined by the method of Ahmad et al. (2014) with slight modifications. Briefly, extraction solvents were dried out from the extracts using vacuum concentrator (RVC 2-18, CHRIST, Germany). The dried extracts were diluted with methanol with initial concentration of $1 \mathrm{mg} / \mathrm{mL}$ and were placed into a 96-well microplate $(100 \mu \mathrm{L})$. The absorbance of the sample was measured at $490 \mathrm{~nm}$ (Abs 1) using microplate reader (iMark ${ }^{\mathrm{TM}}$ Microplate Absorbance Reader, BioRad, United States of America). Then, $0.5 \mathrm{mM}$ DPPH radical (SigmaAldrich, United States of America) in methanol solution $(100 \mu \mathrm{L})$ was added. As the mixture was incubated at $37^{\circ} \mathrm{C}$ for $30 \mathrm{~min}$, the absorbance (Abs 2) was measured again. Gallic acid was used as a positive control with initial stock concentration at $1 \mathrm{mg} / \mathrm{mL}$. Inhibition concentration to scavenge $50 \%$ of DPPH radicals $\left(\mathrm{IC}_{50}\right)$ values were determined according to DPPH scavenging activity (SA) and the SA was calculated using the formula:

$$
\text { Scavening Activity }(\%)=\left[1-\frac{\left(\mathrm{Abs} 2_{\text {sample }}-\mathrm{Abs} 1_{\text {sample }}\right)}{\left(\mathrm{Abs} 2_{\text {control }}-\mathrm{Abs} 1_{\text {control }}\right)}\right] \times 100
$$

\section{FERRIC REDUCING POWER (FRAP) ASSAY}

The ferric reducing power was determined according to Kuda and Yano (2009) using $25 \mu \mathrm{L}$ of methanol diluted dried sample $(1 \mathrm{mg} / \mathrm{mL}), 25 \mu \mathrm{L}$ of phosphate buffers ( $\mathrm{pH}$ 6.6) and $50 \mu \mathrm{L}$ of $0.1 \%$ potassium ferricyanide mixed in a 96-well microplate. Briefly, the mixture was incubated at $37^{\circ} \mathrm{C}$ for $60 \mathrm{~min}$ before adding $25 \mu \mathrm{L}$ of $10 \%$ TCA and 100 $\mu \mathrm{L}$ of distilled water and the absorbance was measured at $655 \mathrm{~nm}$ (Abs 1). Then, $25 \mu \mathrm{L}$ of $0.1 \%$ ferric chloride was added and the absorbance was measured again (Abs 2). The reducing power was calculated as formula:

$$
\begin{aligned}
\text { Reducing Power }= & \left(\mathrm{Abs} 2_{\text {sample }}-\mathrm{Abs} 1_{\text {sample }}\right)- \\
& \left(\mathrm{Abs} 2_{\text {control }}-\mathrm{Abs}_{\text {control }}\right)
\end{aligned}
$$

\section{TOTAL PHENOLIC CONTENT (TPC)}

Sample extracts with the concentration of $1 \mathrm{mg} / \mathrm{mL}(10$ $\mu \mathrm{L}$ ) was mixed with $100 \mu \mathrm{L}$ of $10 \%$ Folin-Ciocalteu reagent (Merck, United States of America). After 5 min, the solution was mixed with $100 \mu \mathrm{L}$ of $7.5 \% \mathrm{Na}_{2} \mathrm{CO}_{3}$ solution and the mixture was left to stand for $60 \mathrm{~min}$. The absorbance was then recorded at $650 \mathrm{~nm}$. Gallic acid was used as standard. The total phenolic content was as gallic acid equivalents by reference to linear equation of the standard curve $\left(y=3.2032 x+0.0574, R^{2}=0.998\right)$ with the initial concentration of $1 \mathrm{mg} / \mathrm{mL}$ (Clarke et al. 2013).

\section{STATISTICAL ANALYSIS}

Statistical analysis was performed using Statistical Packages for the Social Sciences (SPSS) 17.0 software. Significance of differences between each sample was analysed using one-way analysis of variance (ANOVA) 
and the correlation between the antioxidant assays were analysed using Pearson correlation analysis.

\section{RESULTS AND DISCUSSION}

\section{DPPH ASSAY}

According to Shian and Abdullah (2012), antioxidants can be classified into two main groups; primary and secondary antioxidants. The antioxidant molecules that could react and scavenge the free radicals are usually regarded as primary antioxidants. Hence, DPPH assay is used to measure the ability of primary antioxidants from samples in scavenging DPPH radicals, through donating hydrogen atom or electron, thus changed the free radicals into a stable product (Azlim Almey et al. 2010; Mehta \& Gowder 2015; Shian \& Abdullah 2012). Lower $\mathrm{IC}_{50}$ values correspond to higher antioxidant activity, which mean lower concentration needed to scavenge $50 \%$ of DPPH radicals (Maisuthisakul et al. 2007). The DPPH radical scavenging activity ability of the pitcher extracts of three Nepenthes plant species are shown in Table 1. In the DPPH analysis, although there were insignificant differences $(p>0.05), N$. ampullaria showed the highest DPPH scavenging activity $(0.148 \pm 0.04 \mathrm{mg} / \mathrm{mL})$, followed by $N$. rafflesiana $(0.176$ $\pm 0.05 \mathrm{mg} / \mathrm{mL})$ and $N . \times$ hookeriana $(0.234 \pm 0.09 \mathrm{mg} /$ $\mathrm{mL}$ ) (Figure 1).

\section{FRAP ASSAY}

The secondary antioxidant molecules are active in suppressing radical formation and preventing oxidative damage (Shian \& Abdullah 2012). Furthermore, the secondary antioxidants also known as the metal chelator and oxygen scavenger. Hence, ferric reducing power (FRAP) assay is suited for determining the secondary antioxidant capability in the samples, by observing the change in absorbance and the colour change from yellow ferric ion $\left(\mathrm{Fe}^{3+}\right)$ to green-blue ferricyanide $\left(\mathrm{Fe}^{2+}\right)$ complex according to the reducing power (Figure 2) (Zulkefli et al. 2013). As shown in Table 1,N. ampullaria displayed the highest ferric reduction power $(0.009 \pm 0.003 \mathrm{mg} \mathrm{GA} /$ mg dry weight), with the highest gallic acid equivalent concentration compared to the other two species albeit not statistically significant.

\section{TPC ASSAY}

According to Ainsworth and Gillespie (2007), phenolic compounds are outstanding oxygen radical scavengers due to their low electron reduction potential than the oxygen radicals and the phenoxyl radicals are less reactive than the oxygen radicals. Thus, the phenolic compounds could scavenge intermediates of reactive oxygen without promoting further oxidative reactions. In total phenolic content (TPC) assay, the concentration of the phenolic groups can be determined from reaction with the Folin-

TABLE 1. Antioxidant properties of pitchers from different species of Nepenthes. Each value represents mean \pm SD of 5 independent biological replicates

\begin{tabular}{lccc}
\hline \multicolumn{1}{c}{ Sample } & $\begin{array}{c}\mathrm{DPPH}(\mathrm{mg} / \mathrm{mL}) \\
\left(\mathrm{IC}_{50}\right)\end{array}$ & $\begin{array}{c}\text { Total phenolic content } \\
(\mathrm{mg} \mathrm{GA} / \mathrm{mg} \text { of dry weight })\end{array}$ & $\begin{array}{c}\text { FRAP value } \\
(\mathrm{mg} \text { GA/mg dry weight }) \mathrm{ht})\end{array}$ \\
\hline Nepenthes ampullaria & $0.148 \pm 0.04$ & $0.031 \pm 0.019$ & $0.009 \pm 0.003$ \\
Nepenthes $\times$ hookeriana & $0.234 \pm 0.09$ & $0.032 \pm 0.012$ & $0.007 \pm 0.002$ \\
Nepenthes rafflesiana & $0.176 \pm 0.05$ & $0.057 \pm 0.017$ & $0.008 \pm 0.002$ \\
Gallic acid & $0.005 \pm 0.001$ & - & - \\
\hline
\end{tabular}

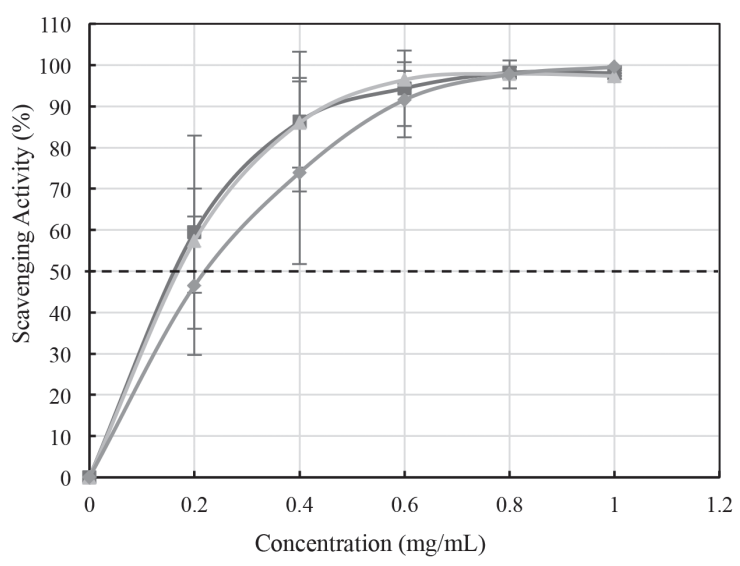

FIGURE 1. DPPH scavenging activity of pitchers from different species of Nepenthes. Each value represents mean \pm SD of 5 independent biological replicates. The markers represent different species, $\square: N$. ampullaria $, \Delta: N$. rafflesiana and $\bullet: N . \times$ hookeriana 
A

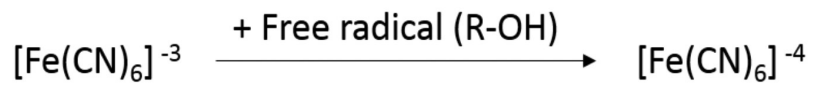

Yellow ferric ion $\left(\mathrm{Fe}^{3+}\right)$

Green-blue ferricyanide $\left(\mathrm{Fe}^{2+}\right)$

B

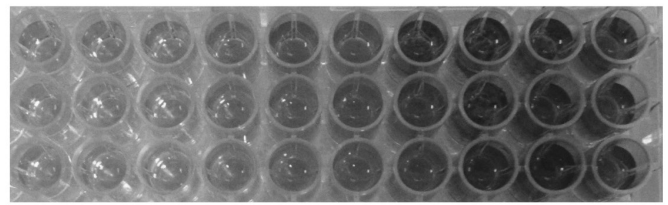

Gallic acid $(0.0039-1 \mathrm{mg} / \mathrm{mL})$

C

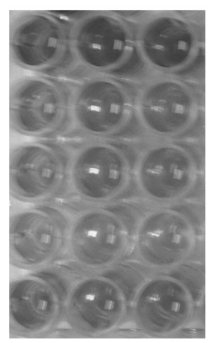

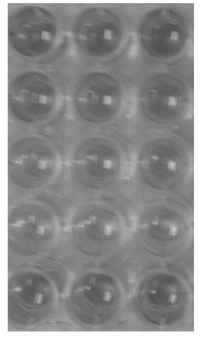

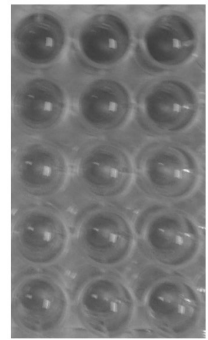

N. ampullaria $(1 \mathrm{mg} / \mathrm{mL}) \quad$ N. x hookeriana $(1 \mathrm{mg} / \mathrm{mL}) \quad$ N. rafflesiana $(1 \mathrm{mg} / \mathrm{mL})$

FIGURE 2. Reduction of ferric ion in FRAP assay. A. Reaction of ferricyanide ion with free radicals. B. Colour differences of assay's solution due to different concentrations of gallic acid (2-folds dilution). The standard was evaluated triplicates. C. Colour changes of assay's solution when introduced with $1 \mathrm{mg} / \mathrm{mL}$ pitcher extracts. Each pitcher extract represents by 5 independent biological replicates (vertical) and 3 technical replicates (horizontal)

A

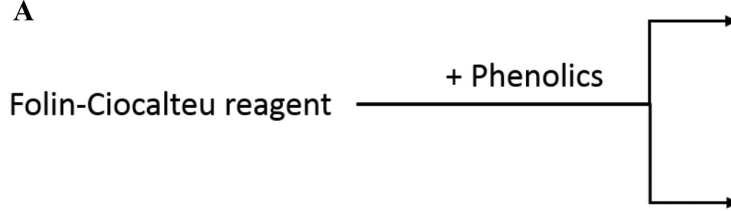

Low Phenolics Content Light Blue

High Phenolics Content

Dark Blue

B

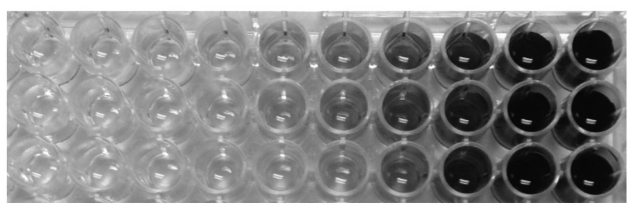

Gallic acid $(0.004-1 \mathrm{mg} / \mathrm{mL})$

C

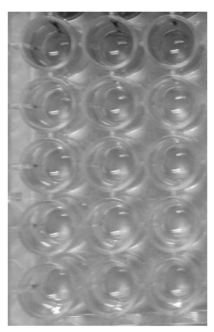

N. ampullaria $(1 \mathrm{mg} / \mathrm{mL})$

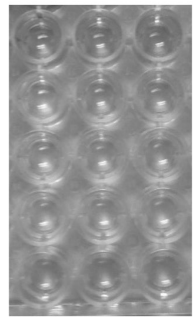

$N$. x hookeriana $(1 \mathrm{mg} / \mathrm{mL})$

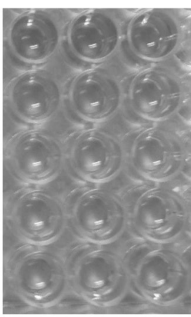

N. rafflesiana $(1 \mathrm{mg} / \mathrm{mL})$

FIGURE 3. The colour changes of Folin-Ciocalteu reagent after introduced with phenolics. A. Reaction of Folin-Ciocalteu reagent with phenolics. B. Colour differences of Folin-Ciocalteu reagent due to different concentrations of gallic acid (2-folds dilution). The standard was evaluated triplicates. C. Colour changes of Folin-Ciocalteu reagent when introduced with $1 \mathrm{mg} / \mathrm{mL}$ pitcher extracts.

Each pitcher extract represents by 5 independent biological replicates (vertical) and 3 technical replicates (horizontal) 
Ciocalteu reagent, as indicated by the blue colour intensity in the reaction mixture (Figure 3) (Shian \& Abdullah 2012). Deeper blue solution indicates higher phenolic concentration. Despite of the insignificant differences ( $p>0.05)$, TPC assay showed that the $N$. rafflesiana had the highest phenolic content $(0.057 \pm 0.017 \mathrm{mg} \mathrm{GA} / \mathrm{mg}$ dry weight) whereas, $N$. ampullaria and $N . \times$ hookeriana showed similar phenolic content (Table 1).

\section{RELATIONSHIP BETWEEN DPHH, FRAP AND TPC}

In order to correlate the antioxidant capacities (DPHH, FRAP) with the TPC, the linear correlation coefficients $(r)$ were calculated for the three plant extracts analysed. Figure 4 shows the relationship between the three antioxidant assays of all the five biological replicates. According to Table 2, our findings showed a significant positive correlation $\left(r=0.671, p<0.01, \mathrm{R}^{2}=43 \%\right)$ between FRAP and TPC, compared to significant negative correlations between DPPH with TPC $(r=-0.671, p<0.01$, $\mathrm{R}^{2}=45 \%$ ). Such high $r$ value suggested that higher phenolic content correlated with higher value of FRAP and lower value of $\mathrm{IC}_{50}$ for DPPH. Hence, the results are in agreement with findings by Clarke et al. (2013) who reported that extracts of plants from Malaysian rainforest displayed a high antioxidant behaviour in both DPPH and FRAP assay and were identified with high phenolic content. Phenolic compounds exhibit strong antioxidant activities due to their ability to act as reducing agents, hydrogen donor and singlet oxygen quenchers (HudaFaujan et al. 2009). Therefore, the significant negative correlations between DPPH with FRAP $(r=-0.801, p<0.01$, $\mathrm{R}^{2}=62 \%$ ) provide insights that antioxidants could lead to a lower DPPH $\mathrm{IC}_{50}$ value and higher FRAP value.

Previous study on antioxidant activity of leaf extracts from other species of Nepenthes, namely N. khasiana and $N$. bicalcarata exhibited decent DPPH scavenging activity by having 10 -fold lower of $\mathrm{IC}_{50}$ values compared to the pitcher extracts (Ismail et al. 2015; Sanusi et al. 2017). These findings showed that the leaf extracts possessed a greater antioxidant activity compared to the pitcher extracts. Furthermore, $N$. bicalcarata leaf extract was also reported to be more active in scavenging DPPH radicals than butylated hydroxytoluene (BHT), a potent synthetic antioxidant that is widely commercialised in foods and pharmaceuticals industries (Ismail et al. 2015; Yehye et al. 2015). Therefore, the leaf extracts might possess higher abundance of metabolites that are responsible for antioxidant activity compared to the pitcher extracts, albeit that pitcher is developed from the leaf. The abundance of those metabolites might be contributed by some external factors such as the growing environment
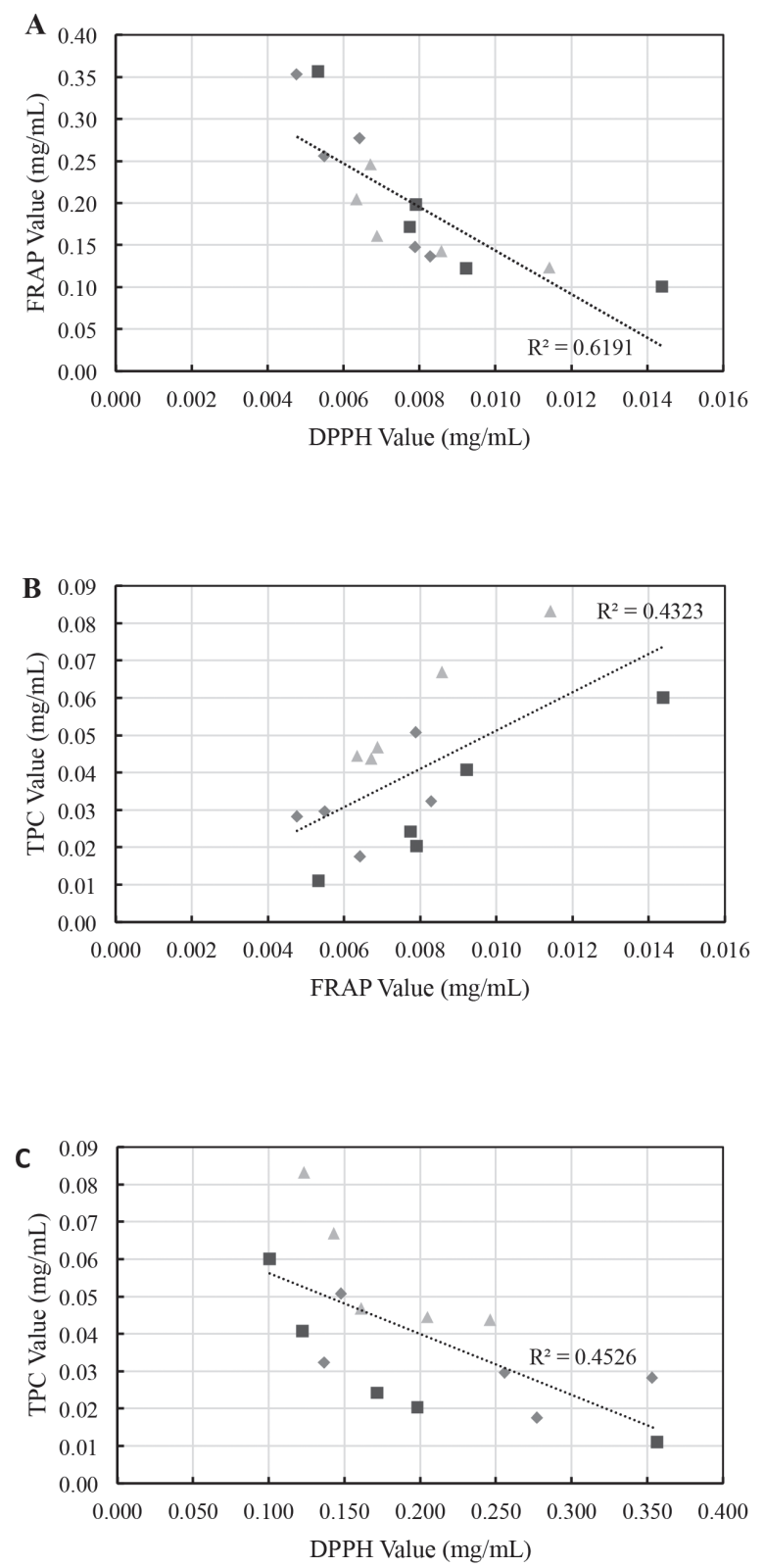

FIGURE 4. Correlation between antioxidant activity assays. A. Correlation between FRAP and DPPH $\mathrm{IC}_{50}$ value. B. Correlation between TPC and FRAP. C. Correlation between TPC and DPPH $\mathrm{IC}_{50}$ value. The markers represent different species, $\mathbf{a}: N$. ampullaria, $\triangle:$ N. rafflesiana and $\bullet: N . \times$ hookeriana

TABLE 2 . The correlation of antioxidant activity assays and total phenolics content of pitchers from different species of Nepenthes

\begin{tabular}{cccc}
\hline Pearson's $r$ & DPPH & FRAP & TPC \\
\hline DPPH & 1.000 & $-0.801^{* *}$ & $-0.671^{* *}$ \\
FRAP & $-0.801^{* *}$ & 1.000 & $0.672^{* *}$ \\
TPC & $-0.671^{* *}$ & $0.672^{* *}$ & 1.000 \\
\hline
\end{tabular}

** Correlation is significant at $p<0.01$ 
of samples (Goh et al. 2016; Kliebenstein 2004; Sampaio et al. 2016).

In the case for N. ampullaria, antioxidant activity was the highest among the three species based on DPPH and FRAP assays, but the phenolic content in the species was lower compared to $N$. rafflesiana. The results suggested that the antioxidant activity from pitcher extracts of $N$. ampullaria may be contributed by different classes of antioxidants molecules, such as terpenes which are also known for their excellent antioxidant activity (Öztürk 2012), or maybe resulted from the synergistic effect of abundant metabolites in the sample (Kopjar et al. 2016). Similar to phenolic, terpenoids also exhibit strong antioxidant capabilities (Adhikari et al.2003). According to Grassmann (2005), essential oils that contain monoterpenes, diterpenes and sesquiterpenes indicate great antioxidant activity and terpenoids also show interesting synergistic actions with other antioxidants such as flavonoids. Therefore, antioxidant activity assay should not only focus on certain metabolite but also includes combination or mixture of secondary metabolites.

\section{CONCLUSION}

In conclusion, despite the lack of statistical significance, pitcher extracts from $N$. ampullaria showed potential as the best radical scavenger with the highest ferric reducing power among the three species, but the highest phenolic content was found in $N$. rafflesiana. The antioxidant activity of pitcher extracts appeared to be much lower than the leaf extracts in previous reports. We showed that higher phenolic content in pitcher extracts is indeed correlated with higher value of FRAP and lower value of $\mathrm{IC}_{50}$ for DPPH. This is the first report on the antioxidant activity of Nepenthes pitchers.

\section{ACKNOWLEDGEMENTS}

We thank Prof. Dr. Jumaat Haji Adam for contributing the pitcher samples. This research was supported by UKM Research University Grant DIP-2014-008.

\section{REFERENCES}

Adam, J.H. \& Hamid, H.A. 2007. Pitcher plants (Nepenthes) recorded from Universiti Kebangsaan Malaysia, Bangi, Selangor, Malaysia. International Journal of Botany 3(1): 71-77.

Adhikari, S., Joshi, R., Patro, B., Ghanty, T., Chintalwar, G., Sharma, A., Chattopadhyay, S. \& Mukherjee, T. 2003. Antioxidant activity of bakuchiol: Experimental evidences and theoretical treatments on the possible involvement of the terpenoid chain. Chemical Research in Toxicology 16(9): 1062-1069.

Ahmad, R., Baharum, S.N., Bunawan, H., Lee, M., Mohd Noor, N., Rohani, E.R., Ilias, N. \& Zin, N.M. 2014. Volatile profiling of aromatic traditional medicinal plant, Polygonum minus in different tissues and its biological activities. Molecules 19(11): 19220-19242.
Ainsworth, E.A. \& Gillespie, K.M. 2007. Estimation of total phenolic content and other oxidation substrates in plant tissues using Folin-Ciocalteu reagent. Nature Protocols 2(4): 875-877.

Aung, H., Chia, L., Goh, N., Chia, T., Ahmed, A., Pare, P. \& Mabry, T. 2002. Phenolic constituents from the leaves of the carnivorous plant Nepenthes gracilis. Fitoterapia 73(5): 445-447.

Azlim Almey, A.A., Ahmed Jalal Khan, C., Syed Zahir, I., Mustapha Suleiman, K., Aisyah, M.R. \& Kamarul Rahim, K. 2010. Total phenolic content and primary antioxidant activity of methanolic and ethanolic extracts of aromatic plants' leaves. International Food Research Journal 17(4): 7.

Barros, L., Ferreira, M.J., Queiros, B., Ferreira, I.C. \& Baptista, P. 2007. Total phenols, ascorbic acid, $\beta$-carotene and lycopene in Portuguese wild edible mushrooms and their antioxidant activities. Food Chemistry 103(2): 413-419.

Carocho, M. \& Ferreira, I.C. 2013. A review on antioxidants, prooxidants and related controversy: Natural and synthetic compounds, screening and analysis methodologies and future perspectives. Food and Chemical Toxicology 51: 15-25.

Clarke, G., Ting, K.N., Wiart, C. \& Fry, J. 2013. High correlation of 2,2-diphenyl-1-picrylhydrazyl (DPPH) radical scavenging, ferric reducing activity potential and total phenolics content indicates redundancy in use of all three assays to screen for antioxidant activity of extracts of plants from the Malaysian rainforest. Antioxidants 2(1): 1-10.

Diplock, A., Charuleux, J.L., Crozier-Willi, G., Kok, F., RiceEvans, C., Roberfroid, M., Stahl, W. \& Vina-Ribes, J. 1998. Functional food science and defence against reactive oxidative species. British Journal of Nutrition 80(1): 77-112.

Goh, H.H., Khairudin, K., Sukiran, N.A., Normah, M.N. \& Baharum, S.N.2016. Metabolite profiling reveals temperature effects on the VOCs and flavonoids of different plant populations. Plant Biology 18: 130-139.

Grassmann, J. 2005. Terpenoids as plant antioxidants. Vitamins \& Hormones 72: 505-535.

Huda-Faujan, N., Noriham, A., Norrakiah,A.\& Babji,A.S. 2009. Antioxidant activity of plants methanolic extracts containing phenolic compounds. African Journal of Biotechnology 8(3): 484-489.

Ismail, N., Kamariah, A., Lim, L. \& Ahmad, N. 2015. Phytochemical and pharmacological evaluation of methanolic extracts of the leaves of Nepenthes bicalcarata Hook. f. International Journal of Pharmacognosy and Phytochemical Research 7(6): 1127-1138.

Khalaf, N.A., Shakya, A.K., Al-Othman, A., El-Agbar, Z. \& Farah, H. 2008. Antioxidant activity of some common plants. Turkish Journal of Biology 32(1): 51-55.

Kliebenstein, D. 2004. Secondary metabolites and plant/ environment interactions: A view through Arabidopsis thaliana tinged glasses. Plant, Cell \& Environment 27(6): 675-684.

Kopjar, M., Lončarić, A. \& Pichler,A. 2016. Synergistic effect of sugars and phenolics on antioxidant activity of pomegranate juice. IFT 13, Annual meeting and Food expo, hlm. 1.utg.

Kuda, T. \& Yano, T. 2009. Changes of radical-scavenging capacity and ferrous reducing power in chub mackerel Scomber japonicus and Pacific saury Cololabis saira during $4^{\circ} \mathrm{C}$ storage and retorting. LWT-Food Science and Technology 42(6): 1070-1075.

Lätti, A.K., Riihinen, K.R. \& Jaakola, L. 2011. Phenolic compounds in berries and flowers of a natural hybrid between 
bilberry and lingonberry (Vaccinium $\times$ intermedium Ruthe). Phytochemistry 72(8): 810-815.

Likhitwitayawuid, K., Kaewamatawong, R., Ruangrungsi, N. \& Krungkrai, J. 1998. Antimalarial naphthoquinones from Nepenthes thorelii. Planta Medica 64(03): 237-241.

Maisuthisakul, P., Suttajit, M. \& Pongsawatmanit, R. 2007. Assessment of phenolic content and free radical-scavenging capacity of some Thai indigenous plants. Food Chemistry 100(4): 1409-1418.

Mehta, S.K. \& Gowder, S.J.T. 2015. Members of antioxidant machinery and their functions. In Basic Principles and Clinical Significance of Oxidative Stress, edited by Gowder, S.J.T. IntechOpen. DOI: 10.5772/6188.

Moran, J.A., Hawkins, B.J., Gowen, B.E. \& Robbins, S.L. 2010. Ion fluxes across the pitcher walls of three Bornean Nepenthes pitcher plant species: Flux rates and gland distribution patterns reflect nitrogen sequestration strategies. Journal of Experimental Botany 61(5): 1365-1374.

Onoja, S.O., Omeh, Y.N., Ezeja, M.I. \& Chukwu, M.N. 2014. Evaluation of the in vitro and in vivo antioxidant potentials of Aframomum melegueta methanolic seed extract. Journal of Tropical Medicine 2014: 159-343.

Öztürk, M. 2012. Anticholinesterase and antioxidant activities of savoury (Satureja thymbra L.) with identified major terpenes of the essential oil. Food Chemistry 134(1): 48-54.

Patel, V.R., Patel, P.R. \& Kajal, S.S. 2010. Antioxidant activity of some selected medicinal plants in western region of India. Advances in Biological Research 4(1): 23-26.

Reddy, A. \& Grace, J.R. 2016. In vitro evaluation of antioxidant activity of methanolic extracts of selected mangrove plants. Medicinal and Aromatic Plants 5(3): 250-255.

Rosli, M.A.F., Azizan, K.A., Baharum, S.N. \& Goh, H.H 2017. Mass spectrometry data of metabolomics analysis of Nepenthes pitchers. Data in Brief 14: 295-297.

Sampaio, B.L., Edrada-Ebel, R. \& Da Costa, F.B. 2016. Effect of the environment on the secondary metabolic profile of Tithonia diversifolia: A model for environmental metabolomics of plants. Scientific Reports 6: 29265.

Sanusi, S.B., Bakar, M.F.A., Mohamed, M., Sabran, S.F. \& Mainasara, M.M.2017. Ethnobotanical, phytochemical, and pharmacological properties of Nepenthes species: A review. Asian Journal of Pharmaceutical and Clinical Research 10(11): 16-19.

Schwallier, R., De Boer, H.J., Visser, N., Van Vugt, R.R. \& Gravendeel, B. 2015. Traps as treats: A traditional sticky rice snack persisting in rapidly changing Asian kitchens. Journal of Ethnobiology and Ethnomedicine 11(24): 1-9.

Shian, T.E. \& Abdullah,A. 2012. Antioxidant properties of three banana cultivars (Musa acuminata 'Berangan','Mas' and 'Raja') extracts. Sains Malaysiana 41(3): 319-324.

Shil, D., Mohanty, J., Das, T., Bhuyan, N., Uriah, T. \& Saleem, T. 2010. Protective role of pitcher of Nepenthes khasiana Hook against dexamethazone induced hyperlipidemia and insulin resistance in rats. International Journal of Research in Pharmaceutical Science 1(2): 195-198.
Shin, K.S., Lee, S.K. \& Cha, B.J. 2007. Antifungal activity of plumbagin purified from leaves of Nepenthes ventricosa $\times$ maxima against phytopathogenic fungi. The Plant Pathology Journal 23(2): 113-115.

Thao, N.P., Luyen, B.T.T., Koo, J.E., Kim, S., Koh, Y.S., Thanh, N.V., Cuong, N.X., Kiem, P. V., Minh, C.V. \& Kim, Y.H. 2016. In vitro anti-inflammatory components isolated from the carnivorous plant Nepenthes mirabilis (Lour.) Rafarin. Pharmaceutical Biology 54(4): 588-594.

Van Thanh, N., Thao, N.P., Huong, P.T.T., Lee, S.H., Jang, H.D., Cuong, N.X., Nam, N.H., Van Kiem, P., Kim, Y.H. \& Van Minh, C. 2015. Naphthoquinone and flavonoid constituents from the carnivorous plant Nepenthes mirabilis and their anti-osteoporotic and antioxidant activities. Phytochemistry Letters 11: 254-259.

Van Thanh, N., Thao, N.P., Huong, P.T.T., Lee, S.H., Jang, H.D., Cuong, N.X., Nam, N.H., Van Kiem, P., Van Minh, C. \& Kim, Y.H. 2015. Two new naphthalene glucosides and other bioactive compounds from the carnivorous plant Nepenthes mirabilis. Archives of Pharmacal Research 38(10): 17741782.

Wang, L.,Zhou, Q.,Zheng, Y. \& Xu, S. 2009. Composite structure and properties of the pitcher surface of the carnivorous plant Nepenthes and its influence on the insect attachment system. Progress in Natural Science 19(12): 1657-1664.

Yehye, W.A., Rahman, N.A., Ariffin, A., Abd Hamid, S.B.,Alhadi, A.A., Kadir, F.A. \& Yaeghoobi, M. 2015. Understanding the chemistry behind the antioxidant activities of butylated hydroxytoluene (BHT): A review. European Journal of Medicinal Chemistry 101: 295-312.

Zulkefli, H.N., Mohamad, J. \& Abidin, N.Z. 2013. Antioxidant activity of methanol extract of Tinospora crispa and Tabernaemontana corymbosa. Sains Malaysiana 42(6): 697-706.

Metabolomics Research Laboratory

Institute of Systems Biology (INBIOSIS)

Universiti Kebangsaan Malaysia

43600 UKM Bangi, Selangor Darul Ehsan

Malaysia

*Corresponding author; email: gohhh@ukm.edu.my

Received: 30 May 2018

Accepted: 19 September 2018 